\title{
Hydrotreatment of Cellulose-Derived Bio-Oil Using Copper and/or Zinc Catalysts Supported on Mesoporous Silica-Alumina Synthesized from Lapindo Mud and Catfish Bone
}

\author{
Fahri Swasdika, Wega Trisunaryanti*, and Iip Izul Falah \\ Department of Chemistry, Faculty of Mathematics and Natural Sciences, Universitas Gadjah Mada, \\ Sekip Utara, Yogyakarta 55281, Indonesia
}

\section{*Corresponding author:}

email:wegats@ugm.ac.id

Received: October 13, 2019

Accepted: April 19, 2020

DOI: $10.22146 /$ ijc. 50558

\begin{abstract}
Catalysts comprising copper and/or zinc supported on mesoporous silicaalumina (MSA) with a high Si/Al ratio were prepared by wet impregnation method. This study investigated the preparation, characterization, and catalytic application of the prepared catalysts for hydrotreatment of cellulose-derived bio-oil. The wet impregnation was performed by dispersing $\mathrm{Cu}\left(\mathrm{NO}_{3}\right)_{2} \cdot 3 \mathrm{H}_{2} \mathrm{O}$ and/or $\mathrm{Zn}\left(\mathrm{NO}_{3}\right)_{2} \cdot 4 \mathrm{H}_{2} \mathrm{O}$ aqueous solution into MSA, followed by calcination and reduction under $\mathrm{H}_{2}$ gas stream. The acidity test revealed that metal addition on MSA support increases the acidity of catalysts. During hydrotreatment of cellulose-derived bio-oil CuZn/MSA with total acidity, copper loading, zinc loading, and specific surface area of $24.86 \mathrm{mmol} \mathrm{g}^{-1}, 5.23 \mathrm{wt} . \%, 3.15 \mathrm{wt} . \%$, and $170.77 \mathrm{~m}^{2} \mathrm{~g}^{-1}$, respectively, exhibited the best performance compared to other prepared catalysts with 90.49 wt.\% conversion of liquid product.
\end{abstract}

Keywords: hydrotreatment; bio-oil; catalysis; bifunctional catalyst; mesoporous silicaalumina

\section{- INTRODUCTION}

Lignocellulose biomass is a promising alternative source of petroleum for fuels and chemicals production due to its abundance, non-edible, and relatively low cost [1]. It mainly consists of cellulose (40-60 wt.\%), hemicellulose (15-30 wt.\%), and lignin (10-25 wt.\%) [2]. It could be converted to fuels via a thermochemical process such as pyrolysis. Pyrolysis of biomass usually involves a thermal decomposition of organic materials under an inert atmosphere. Products of biomass pyrolysis mainly consist of bio-oil, char, and gases. Bio-oil produced by biomass pyrolysis has demonstrated as a suitable fuel for heat generation in boiler systems and power generation in some diesel engines [3-4]. However, the produced bio-oil is unusable in internal combustion engines due to its high oxygen content, low heating value, and high acidity [5]. Therefore, an upgrading process to improve the quality of bio-oil is needed.

One of the commonly employed methods for bio-oil upgrading is a hydrotreatment [6-7]. This method selectively removes oxygen from bio-oil through a catalytic reaction using hydrogen in the presence of a heterogeneous catalyst. Conventional hydrotreating catalysts such as sulfided NiMo and CoMo have been widely used for upgrading bio-oil. However, the sulfided catalysts have problems with sulfur usage and product contamination [8]. Pt-based catalysts have been considered as alternatives due to their high activity for hydrotreatment of bio-oil [9-10]. However, scarcity and the high price of noble metals are the main problems for industrial-scale applications [7]. Other transition metals such as $\mathrm{Cu}$ and $\mathrm{Zn}$ have attracted considerable attention as hydrotreatment catalysts due to their unique performance in the hydrogenation of esters to alcohol [11-13] and $\mathrm{CO}_{2}$ [14-15]. However, there is a limited report of $\mathrm{Cu}-\mathrm{Zn}$ based catalysts for hydrotreatment of bio-oil. The previous study showed that the catalyst containing $\mathrm{Cu}$ and $\mathrm{Zn}$ metals have good activity in the conversion of cyclic esters into hydrocarbon [16].

Copper-based catalysts exhibit excellent catalytic performance for hydrogenation of esters to alcohols 
because they can catalyze selective hydrogenation of carbon-oxygen bonds and are relatively inactive for carbon-carbon bond hydrogenolysis [17]. Copper by itself is usually not active enough, resistant to sintering, nor mechanically stable enough for industrial use [11]. Therefore, promoters such as $\mathrm{Zn}$ are needed to improve it. The presence of $\mathrm{Zn}$ can promote the dispersion of $\mathrm{Cu}$ particles and enhance the reducibility of the copper oxide phase [12].

In a heterogeneous catalyst, a catalyst support also plays an important role in improving the efficiency of hydrotreatment processes. Because the hydrotreatment of aromatics and/or oxygen-containing compounds over bifunctional catalysts involves (de)hydrogenation on metallic centers and isomerization/cracking on acid centers [18]. Porous materials such as zeolite have been widely used as catalyst or catalyst support in the industry due to its unique characteristics such as high surface area, acidity, and thermal stability [19]. However, the application of zeolite is limited to small molecules due to its microporosity. Therefore, porous material with a relatively larger pore would be necessary. Mesoporous silica-alumina (MSA) has received great attention for replacing zeolite as support [9,20-21]. The MSA as catalyst support can be successfully synthesized from natural resources such as Lapindo mud and catfish bone gelatin [22-23]. The high content of $\mathrm{Si}$ and $\mathrm{Al}$ in Lapindo mud makes great attention to utilize Lapindo mud as a source to produce $\mathrm{Si}$ and $\mathrm{Al}$ precursor [22-24]. Catfish bone constitutes one of the primary waste associated with industry by-products and is considered as a raw material for gelatin production. Meanwhile, gelatin can be used as an organic template due to its high content of $\mathrm{N}-\mathrm{H}$ groups which tend to strongly interact with xylanol $(\mathrm{Si}-\mathrm{OH})$ group on the silicate species via multiple hydrogen bonding. However, research on the use of gelatin from catfish bone as a template for synthesis of MSA is still rare. Moreover, the utilization of natural resources in the manufacture of MSA may reduce the production cost.

In the present work, the MSA with a high $\mathrm{Si} / \mathrm{Al}$ molar ratio was synthesized using precursor derived from Lapindo mud and catfish bone. Lapindo mud was used as the source to produce $\mathrm{Si}$ and $\mathrm{Al}$ precursors, while the catfish bone was used as the source to produce gelatin as the template precursor. The MSA was used as a support material of copper and/or zinc metals as catalysts for hydrotreatment of bio-oil. a-Cellulose was used as a model of biomass.

\section{- EXPERIMENTAL SECTION}

\section{Materials}

Catfish bone waste was collected from Tegalrejo Village, Central Java, Indonesia. Lapindo mud was collected from Sidoarjo Regency, East Java, Indonesia. Hydrochloric acid ( $\mathrm{HCl} 37 \%)$ was purchased from Mallinckrodt. Copper nitrate trihydrate $\left(\mathrm{Cu}\left(\mathrm{NO}_{3}\right)_{2} \cdot 3 \mathrm{H}_{2} \mathrm{O}\right.$, purity $\left.99 \%\right)$, zinc nitrate tetrahydrate $\left(\mathrm{Zn}\left(\mathrm{NO}_{3}\right)_{2} \cdot 4 \mathrm{H}_{2} \mathrm{O}\right.$, purity $\left.98.5 \%\right)$, ammonia $\left(\mathrm{NH}_{3} 25 \%\right)$ and sodium hydroxide $(\mathrm{NaOH}$, purity $99 \%)$ were purchased from Merck. a-Cellulose was purchased from Sigma-Aldrich. Hydrogen $\left(\mathrm{H}_{2}\right)$ and nitrogen $\left(\mathrm{N}_{2}\right)$ gas were supplied by PT. Samator Ltd.

\section{Procedure}

\section{Extraction of silica and alumina from Lapindo mud}

Silica $\left(\mathrm{SiO}_{2}\right)$ and alumina $\left(\mathrm{Al}_{2} \mathrm{O}_{3}\right)$ extraction had been conducted by the following procedure. The Lapindo mud was dried and sieved up to 100 mesh. 100 $\mathrm{g}$ of dried mud was refluxed in $400 \mathrm{~mL}$ of $6.0 \mathrm{M} \mathrm{HCl} \mathrm{(1:4,}$ $\mathrm{w} / \mathrm{v}$ ) at $90{ }^{\circ} \mathrm{C}$ and kept under magnetic stirring for $5 \mathrm{~h}$. $\mathrm{The} \mathrm{Al}$ ions and other soluble metals would be dissolved in the $\mathrm{HCl}$ solution. Therefore, it will treat further by adding $150 \mathrm{~mL}$ of $6.0 \mathrm{M} \mathrm{NaOH}(2: 3, \mathrm{v} / \mathrm{v})$ up to $\mathrm{pH}$ of 8.0, then filtrated to remove the unneeded metals. The $\mathrm{Al}$ ions were then precipitated by injecting $\mathrm{CO}_{2}$ gas into the filtrate. The precipitate was filtered, followed by washing using demineralized water. The slurry was dried at $50{ }^{\circ} \mathrm{C}$ and then calcined at $500{ }^{\circ} \mathrm{C}$ for $5 \mathrm{~h}$ to obtain $\mathrm{Al}_{2} \mathrm{O}_{3}$ material. Meanwhile, the silica was extracted from Lapindo mud by refluxing the mud residue of aluminium extraction in $400 \mathrm{~mL}$ of $6.0 \mathrm{M} \mathrm{NaOH}(1: 4, \mathrm{w} / \mathrm{v})$ at $90^{\circ} \mathrm{C}$ and kept this under magnetic stirring for $5 \mathrm{~h}$. The filtrate was then treated by adding a $2.0 \mathrm{M} \mathrm{HCl}$ solution to give the solution with a $\mathrm{pH}$ of 8 . The precipitate was filtered followed by washing using demineralized water. The slurry was dried at $100^{\circ} \mathrm{C}$ to obtain solid $\mathrm{SiO}_{2}$ material. 
The chemical composition of silica and alumina was then analyzed using X-Ray Fluorescence (XRF, PANalytical Minipal4).

\section{Extraction of gelatin from catfish bone}

Gelatin extraction was carried out according to Marsuki et al. [22] and Kusumastuti et al. [23] with a slight modification. The extraction was prepared by immersing $100 \mathrm{~g}$ of catfish bone in $500 \mathrm{~mL}$ of $0.1 \mathrm{M} \mathrm{NaOH}$ solution $(1: 5 \mathrm{w} / \mathrm{v})$ for $24 \mathrm{~h}$ to remove non-collagenous proteins, then washing with demineralized water to remove the remaining non-collagenous protein until the washed water reached neutral $\mathrm{pH}$. The residue was then immersed with $500 \mathrm{~mL}$ of $1.5 \mathrm{M} \mathrm{HCl}$ solution $(1: 5 \mathrm{w} / \mathrm{v})$ for $1 \mathrm{~h}$ for demineralization, followed by washing with demineralized water until the wash water reached neutral $\mathrm{pH}$. To produced gelatin, the bone was refluxed with $400 \mathrm{~mL}$ of demineralized water $(1: 4 \mathrm{w} / \mathrm{v})$ at $90^{\circ} \mathrm{C}$ for $5 \mathrm{~h}$ then evaporated at $50{ }^{\circ} \mathrm{C}$. The dry gelatin was characterized using Fourier Transform-Infrared (FT-IR, Thermo Nicolet iS10).

\section{Preparation of mesoporous silica-alumina}

In a typical synthesis of MSA, $0.017 \mathrm{~g}$ of alumina and $3.0 \mathrm{~g}$ of silica was dissolved in $80 \mathrm{~mL}$ of $\mathrm{NaOH}$ solution (molar ratio $\mathrm{NaOH}$ to $\left(\mathrm{SiO}_{2}+\mathrm{Al}_{2} \mathrm{O}_{3}\right)$ of $\left.1: 1\right)$ under constant stirring at $40{ }^{\circ} \mathrm{C}$. Meanwhile, $3.0 \mathrm{~g}$ of gelatin was dissolved in $80 \mathrm{~mL}$ of distilled water under constant stirring at $40{ }^{\circ} \mathrm{C}$, and the solution was slowly added into the silica-alumina solution. Afterward, the mixture was adjusted to $\mathrm{pH} 10$ using $1.0 \mathrm{M} \mathrm{HCl}$ solution while stirring process was kept for the next $1 \mathrm{~h}$. The formed gel solution was transferred into an autoclave and hydrothermally treated at $100{ }^{\circ} \mathrm{C}$ for $24 \mathrm{~h}$. The solid obtained from hydrothermal treatment was filtered, followed by washing with distilled water. The solid was dried at $80{ }^{\circ} \mathrm{C}$ for overnight. Finally, the solid was calcined at $550^{\circ} \mathrm{C}$ for $5 \mathrm{~h}$ and the resulting solid was labeled as MSA. The MSA has a Si/Al molar ratio of 115.34 based on ICP-AES (Shimadzu ICPE-9820) analysis.

\section{Metal impregnation on MSA}

Copper and zinc metals were sequentially impregnated onto the prepared MSA by the wet impregnation method, in which $\mathrm{Zn}$ metal was firstly loaded, followed by Cu metals. The mixture of MSA-salt solution was stirred for $24 \mathrm{~h}$ at room temperature and dried at $100^{\circ} \mathrm{C}$ for overnight. The catalysts were calcined at $500{ }^{\circ} \mathrm{C}$ for $3 \mathrm{~h}$ under the $\mathrm{N}_{2}$ gas stream, followed by a reduction under the $\mathrm{H}_{2}$ gas stream at $450{ }^{\circ} \mathrm{C}$ for $3 \mathrm{~h}$. The obtained catalyst was denoted as CuZn/MSA. Further, $\mathrm{ZnCu} / \mathrm{MSA}$ (Cu metals was firstly loaded followed by $\mathrm{Zn}$ metals), Zn/MSA (only zinc metals), and Cu/MSA (only copper metals) catalysts were synthesized following the same method of synthesis CuZn/MSA.

\section{Catalyst characterization}

The acidity of the catalyst was determined using the gravimetric method, with $\mathrm{NH}_{3}$ as the basic adsorbate. The crystallinity of the catalysts was characterized by Xray diffractometry (XRD, Rigaku Miniflex 600) with CuKa irradiation $(\lambda=0.154 \mathrm{~nm})$ in the $2 \theta$ range of 2$80^{\circ}$. Pore characteristics of the catalysts were analyzed using a gas sorption analyzer (GSA, Quantachrome Touchwin Series) and evaluated by Brunauer-EmmettTeller (BET) and Barrett-Joyner-Halenda (BJH) theories. The metal content of the catalysts was analyzed using an inductively coupled plasma atomic emission spectroscopy (ICP-AES, Shimadzu ICPE-9820). TEM images were determined by a JEOL-JEM-1400 microscope with an electron beam of $120 \mathrm{kV}$.

\section{Hydrotreatment process}

Cellulose was pyrolyzed at $600{ }^{\circ} \mathrm{C}$ for $2 \mathrm{~h}$ under the $\mathrm{N}_{2}$ gas stream to produce bio-oil. The liquid product (bio-oil) obtained from the pyrolysis of cellulose was treated at $450{ }^{\circ} \mathrm{C}$ for $1 \mathrm{~h}$ under the $\mathrm{H}_{2}$ gas stream in a semi-batch stainless steel reactor (id: $4.5 \mathrm{~cm}$, od: $4.8 \mathrm{~cm}$, length: $30 \mathrm{~cm}$ ) using catalysts synthesized in this study. The catalyst to feed ratio was $1: 30(\mathrm{w} / \mathrm{w})$. The yield percentage was calculated using Eq. (1), (2), and (3).

Coke $($ wt. $\%)=\frac{\text { Wcoke }}{\text { Wfeed }} \times 100 \%$

Liquid $\left(\right.$ wt.\%) $=\frac{\text { Wliquid }}{\text { Wfeed }} \times 100 \%$

Gas $($ wt. $\%)=[100-$ Liquid - Coke $] \%$

The liquid products obtained from hydrotreatment bio-oil were characterized by using Gas Chromatography-Mass Spectroscopy (Shimadzu QP 
2010 S). The percentage of the product was calculated using Eq. (4).

Product $=(\%$ Area $) \times(\%$ Liquid $)$

\section{- RESULTS AND DISCUSSION}

\section{Characterization of Catfish Bone Gelatin}

The FT-IR spectrum of the catfish bone gelatin is presented in Fig. 1. Generally, the FT-IR spectrum of gelatin shows five characteristic polypeptide absorption bands called amide A, B, I, II, and III. Amide A observed at $3392 \mathrm{~cm}^{-1}$ corresponds to the stretching vibration of N$\mathrm{H}$ group coupled with hydrogen bonding. A free $\mathrm{N}-\mathrm{H}$ stretching vibration normally occurs in the range of $3400-$ $3440 \mathrm{~cm}^{-1}$. When the $\mathrm{N}-\mathrm{H}$ group of a peptide is involved in a hydrogen bond, the position is shifted to lower frequencies [25]. Amide B was observed at $2939 \mathrm{~cm}^{-1}$ which corresponds to the asymmetric stretching vibrations of $=\mathrm{C}-\mathrm{H}$ as well as $\mathrm{NH}_{3}$ [25-26].

Amide I which appears at $1652 \mathrm{~cm}^{-1}$ is mainly due to $\mathrm{C}=\mathrm{O}$ stretching vibration coupled to $\mathrm{CN}$ contribution, $\mathrm{CCN}$ deformation, and in-plane bending modes [25]. The amide II band exhibited at $1537 \mathrm{~cm}^{-1}$ corresponds to an out of phase combination of $\mathrm{C}-\mathrm{N}$ stretching vibration coupled to in-plane $\mathrm{NH}$ deformation modes of peptide group [25]. The amide III band at $1242 \mathrm{~cm}^{-1}$ represents the combination between $\mathrm{CN}$ stretching vibrations and $\mathrm{NH}$ deformation from the amide linkage as well as the absorptions arising from wagging vibrations of $\mathrm{CH}_{2}$ groups [25-26]. Gelatin which contains a lot of $\mathrm{NH}$ groups

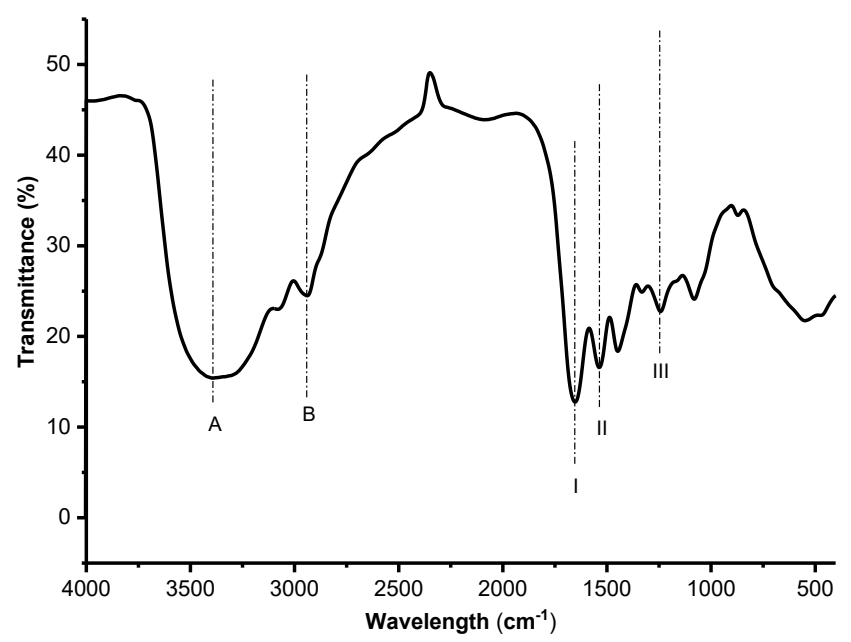

Fig 1. The spectrum of catfish bone gelatin can be used as a template in preparation of MSA materials. These $\mathrm{N}-\mathrm{H}$ groups tend to strongly interact with sylanol groups $(\mathrm{Si}-\mathrm{OH})$ via multiple hydrogen bonds [27].

\section{Extraction of Silica and Alumina from Lapindo Mud}

XRF analysis showed that Lapindo mud contains various kinds of metals such as $\mathrm{Fe}(36.90 \%), \mathrm{Si}(35.10 \%)$, Al (11.00\%), Ca (6.95\%), K (3.52\%), Ti (2.09\%), S (1.10\%), and others (3.34\%). The high content of Si and $\mathrm{Al}$ in Lapindo mud makes it one of the resources that can be utilized to produce $\mathrm{Si}$ and Al. To produce them, the other metals should be removed by several chemical and physical steps, such as acid leaching and precipitation using an acid or alkaline followed by filtration. In the first step, acid extraction using hydrochloric acid was conducted to destroy the crystalline aluminosilicate phase to release free aluminium ions. Various metals could be dissolved at this condition such as Fe, therefore, the addition of $6.0 \mathrm{M} \mathrm{NaOH}$ could be used to remove them. Some impurities will be precipitated into $\mathrm{M}(\mathrm{OH}) \mathrm{n}$, while $\mathrm{Al}$ remains dissolved in the solution. The $\mathrm{Al}$ ions can be precipitated by injecting $\mathrm{CO}_{2}$ gas into the solution followed by filtration and washing using demineralized water to obtain alumina solid.

The silica was extracted from solid residue alumina extraction by refluxing the solid in $6.0 \mathrm{M} \mathrm{NaOH}$. The silica will be reacted with $\mathrm{NaOH}$ to produce $\mathrm{Na}_{2} \mathrm{SiO}_{3(\text { aq) }}$. The impurities will be removed in the solid residue. By adjusting the $\mathrm{pH}$ with the addition of $\mathrm{HCl}$ to $\mathrm{pH}$ of 8.0, silica could be obtained as the precipitate. In this study, the yield of alumina extraction is 10.83 wt.\% with a purity of $84.5 \mathrm{wt} . \%$ based on XRF analysis. Meanwhile, the yield of silica extraction is $21.47 \mathrm{wt} . \%$ with a purity of $96.3 \mathrm{wt}$ \% based on XRF analysis.

\section{Characterization of MSA and Catalysts Prepared}

Fig. 2 shows the FT-IR spectra of MSA before and after calcination. The spectra before calcination indicate the characteristics of the gelatin template. The bands observed around 1547 and $2949 \mathrm{~cm}^{-1}$ are corresponding to the amide II and B from the gelatin structure, respectively. This result is in agreement with the previous

Fahri Swasdika et al. 


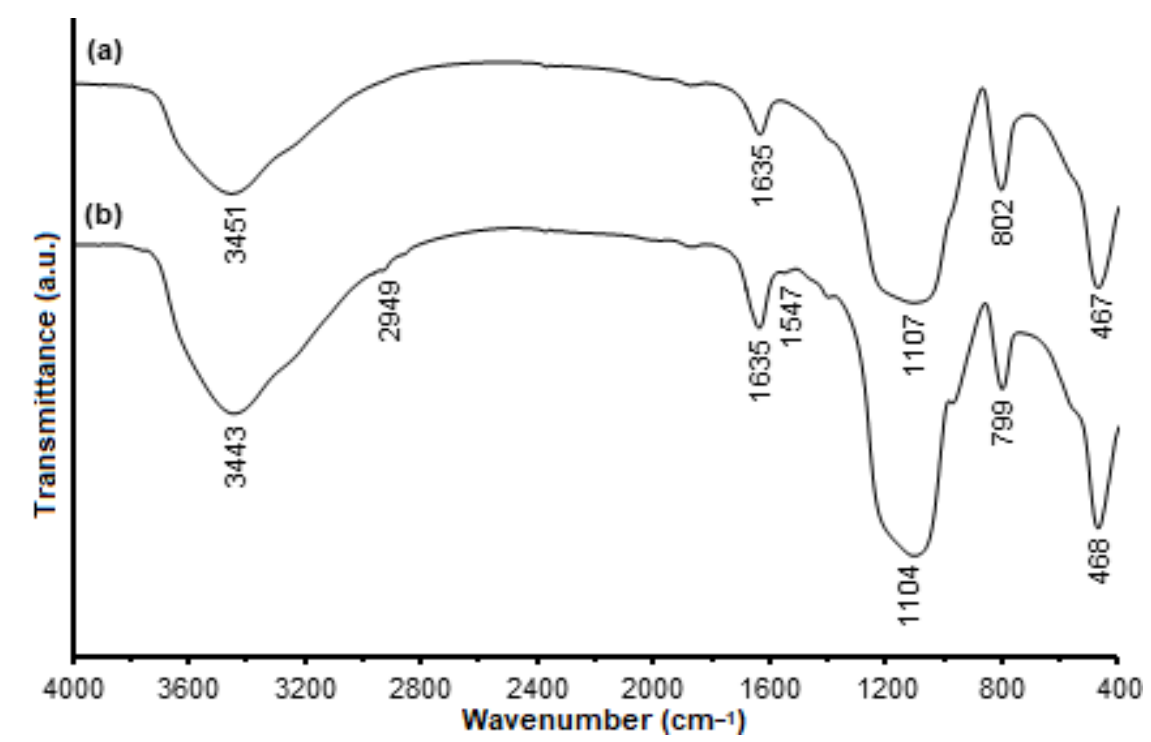

Fig 2. FT-IR spectra of MSA (a) before calcination and (b) after calcination

study that after hydrothermal MSA still contains gelatin [23]. In Fig. 2(b), the bands which correspond to gelatin were not observed. It is proven that the calcination process is effective to eliminate gelatin from the MSA framework. The characteristics of the silica-alumina material were observed in MSA material before calcination as well as after calcination. There are strong bands around at 1100 and 799 , which correspond to stretching asymmetric, symmetric stretching of $\mathrm{T}-\mathrm{O}$, respectively [28]. The absorption band at $468 \mathrm{~cm}^{-1}$ refers to the bending vibration of T-O-T [29]. The band at $3400 \mathrm{~cm}^{-1}$ corresponds to $\mathrm{OH}$ stretching vibration bound to $\mathrm{Si}$ or $\mathrm{Al}$, as well as the adsorbed $\mathrm{H}_{2} \mathrm{O}$ molecule on the MSA surface [23]. The molecular vibration of water molecules is confirmed by the presence of an absorption band at $1635 \mathrm{~cm}^{-1}$ which corresponds to the bending vibration of $\mathrm{O}-\mathrm{H}$.

Fig. 3 shows the XRD patterns of the synthesized MSA and impregnated catalysts. It was observed that MSA is amorphous, as indicated by the single broad peak at $2 \theta$ of $21^{\circ}$ that arises from the lack of an ordered crystalline structure [30]. The XRD patterns of modified MSA are also presented in Fig. 4. The XRD pattern of $\mathrm{Cu} / \mathrm{MSA}$ shows peaks at $2 \theta$ of $36.2^{\circ}$ due to the formation of $\mathrm{CuO}$ crystallite. In contrast, $\mathrm{ZnCu} / \mathrm{MSA}$ and CuZn/MSA show a peak at $2 \theta$ of $36.0^{\circ}$ indicating the presence of the $\mathrm{ZnO}$ phase together with the peaks at $2 \theta$ of

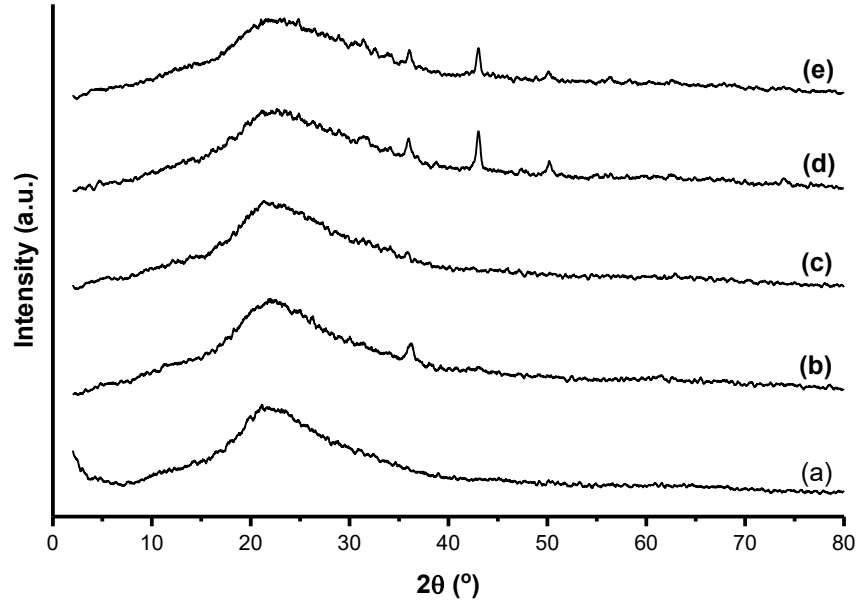

Fig 3. XRD pattern of (a) MSA, (b) Cu/MSA, (c) $\mathrm{Zn} / \mathrm{MSA}$, (d) $\mathrm{ZnCu} / \mathrm{MSA}$, and (e) CuZn/MSA

43.1 and $50.3^{\circ}$ corresponding to the metallic $\mathrm{Cu}$ phase [31]. No diffraction of zinc species was found in $\mathrm{Zn} / \mathrm{MSA}$ samples. This indicates that zinc species are well dispersed at the surface and/or in the channel of MSA [12,32]. The proposed structure of $\mathrm{Cu}$ and/or $\mathrm{Zn}$ supported on MSA was depicted in Fig. 4. MSA has unbalance charge due to the presence of $\mathrm{Al}$ atoms in the structure, therefore naturally it was neutralized with the cation such as $\mathrm{Na}, \mathrm{Ca}, \mathrm{Mg}$, etc. In this case, the $\mathrm{Zn}$ and $\mathrm{Cu}$ cation was impregnated on the MSA structure and it can act to balance the charge by binding with the $\mathrm{O}$ atom closest to the $\mathrm{Al}$ atom. 


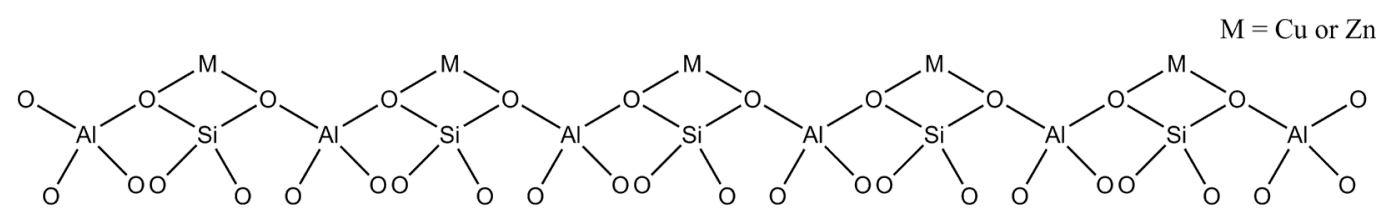

Fig 4. The proposed structure of $\mathrm{Cu}$ and/or $\mathrm{Zn}$ supported on MSA

The nitrogen adsorption-desorption isotherm of the synthesized and modified MSA is presented in Fig. 5. It clearly shows that all samples are classified as type IV isotherm according to IUPAC classification, with the hysteresis loops type $\mathrm{H} 1$. The formation of hysteresis loops that were seen from the relative pressure of 0.63 is probably due to the capillary condensation of nitrogen in the pores. The hysteresis loops indicate the characteristics of mesoporous materials. This fact can be confirmed by the pore size distribution profile of the catalysts as shown in Fig. 6. It was observed that all catalyst has a pore size distribution within the range of 2-25 $\mathrm{nm}$.

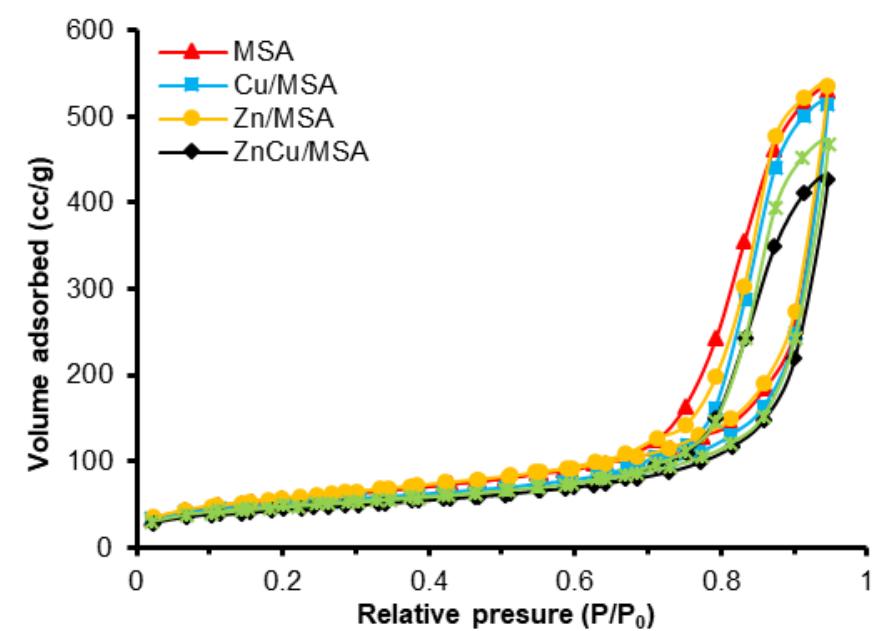

Fig 5. $\mathrm{N}_{2}$ adsorption-desorption isotherm of synthesized and modified MSA
The textural properties of synthesized and modified MSA are listed in Table 1. It can be seen that metal loading leads to a decrease in the surface area. This indicates that the metal particles are dispersed, covered, and occupied on the surface and the pore of MSA. There is no significant change in surface area in $\mathrm{Zn} / \mathrm{MSA}$ samples. This phenomenon confirms that zinc species are well dispersed in MSA. The total amount of acidity has been determined by using ammonia base vapor as the adsorbate. The acidity of catalysts is summarized in Table 1. It indicates that when metal is loaded on MSA, the acidity improves. The empty orbitals of the $4 \mathrm{p}$ orbital

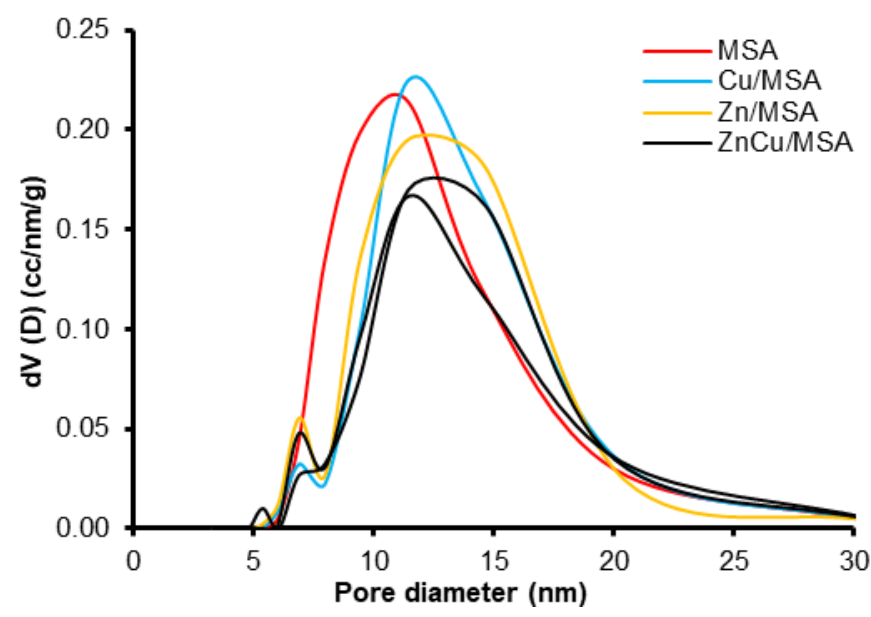

Fig 6. The pore size distribution of synthesized and modified MSA

Table 1. Composition, textural properties, and acidity of catalysts

\begin{tabular}{lcccccc}
\hline \multirow{2}{*}{ Sample } & \multicolumn{2}{c}{ Composition $^{\mathrm{a}}(\mathrm{wt} . \%)$} & \multirow{2}{*}{$\begin{array}{c}\mathrm{S}_{\mathrm{BET}}{ }^{\mathrm{b}} \\
\left(\mathrm{m}^{2} / \mathrm{g}\right)\end{array}$} & $\begin{array}{c}\text { Pore volume }^{\mathrm{b}} \\
(\mathrm{cc} / \mathrm{g})\end{array}$ & $\begin{array}{c}\text { Pore diameter }^{\mathrm{b}} \\
(\mathrm{nm})\end{array}$ & $\begin{array}{c}\text { Acidity }^{\mathrm{c}} \\
(\mathrm{mmol} / \mathrm{g})\end{array}$ \\
\cline { 2 - 5 } MSA & $\mathrm{Cu}$ & $\mathrm{Zn}$ & 200.52 & 0.817 & 8.19 & 15.53 \\
$\mathrm{Cu} / \mathrm{MSA}$ & 3.00 & 0.00 & 179.96 & 0.797 & 8.86 & 19.95 \\
Zn/MSA & 0.00 & 3.88 & 207.54 & 0.830 & 8.00 & 21.69 \\
ZnCu/MSA & 4.94 & 3.93 & 158.30 & 0.632 & 8.40 & 23.95 \\
CuZn/MSA & 5.23 & 3.15 & 170.77 & 0.727 & 8.51 & 24.86 \\
\hline
\end{tabular}

${ }^{a}$ Metal loadings were determined by an inductively coupled plasma atomic emission spectroscopy. ${ }^{\mathrm{b} S B E T}$ and pore volumes and diameters of the catalysts were calculated using BET and BJH theory, respectively. ${ }^{c}$ Acidity of the catalysts was determined gravimetrically using $\mathrm{NH}_{3}$ gas as a basic adsorbate 
in each metal act as Lewis acid, which contributes to the total acidity of the catalysts. Herein, it should be noted that CuZn/MSA exhibits higher acidity than other catalysts.

Fig. 7 shows the TEM micrograph of the MSA. The TEM micrograph shows that the MSA has a wormholelike structure. This result is similar to those of the TEM micrograph of MSA that were synthesized on previous reports [22-23]. The homogeneity of the MSA pore size is relatively low due to the use of a gelatin template which has a wide molecular weight distribution range. The dark spots as shown by the arrow in Fig. 7 were observed in $\mathrm{CuZn} / \mathrm{MSA}$, indicating that metal particles are dispersed well in the MSA matrix.

\section{Catalytic Performance}

To examine the catalytic properties of synthesized and modified MSA, all samples were tested in the hydrotreatment of bio-oil. Bio-oil was obtained from the pyrolysis of cellulose. Cellulose-derived bio-oil is physically dark brown, thick, and smoke-smell. GC-MS data show that bio-oil contains various oxygenated compounds including ether, aldehyde, ketone, acid, ester, furan, anhydride, and other miscellaneous oxygenates (Table 2). The major product in bio-oil is 1-hydroxy-2-propanone, which is about $20.14 \%$.

Hydrotreatment of cellulose-derived bio-oil was carried out with and without a catalyst. Fig. 8 shows the
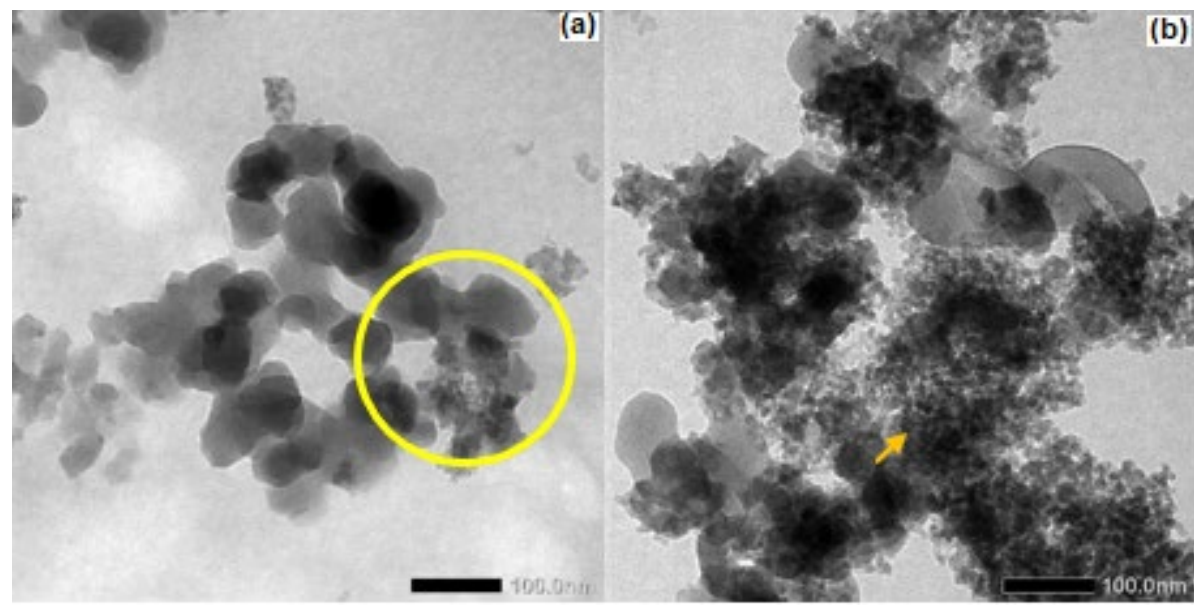

Fig 7. TEM micrograph of MSA (a) and CuZn/MSA (b)

Table 2. Chemical composition of cellulose-derived bio-oil

\begin{tabular}{lcc|lcc}
\hline Compounds & Formula & Content (\%) & Compounds & Formula & Content (\%) \\
\hline 1-Hidroxy-2-propanone & $\mathrm{C}_{3} \mathrm{H}_{6} \mathrm{O}_{2}$ & 20.14 & 1-Acetyloxy-2-propanone & $\mathrm{C}_{4} \mathrm{H}_{6} \mathrm{O}_{2}$ & 1.16 \\
2,3-Butanedione & $\mathrm{C}_{4} \mathrm{H}_{6} \mathrm{O}_{2}$ & 13.53 & 3-Pentanone & $\mathrm{C}_{5} \mathrm{H}_{10} \mathrm{O}$ & 0.85 \\
Methanoic acid & $\mathrm{CH}_{2} \mathrm{O}_{2}$ & 12.72 & 2-Butanone & $\mathrm{C}_{4} \mathrm{H}_{8} \mathrm{O}$ & 0.69 \\
Etanoic acid & $\mathrm{C}_{2} \mathrm{H}_{4} \mathrm{O}_{2}$ & 12.34 & 3-Methyl-1,2-cyclopentadione & $\mathrm{C}_{6} \mathrm{H}_{8} \mathrm{O}_{2}$ & 0.68 \\
2-Furancarboxaldehyde & $\mathrm{C}_{5} \mathrm{H}_{4} \mathrm{O}_{2}$ & 10.61 & 2-Methyl-2-cyclopenten-1-one & $\mathrm{C}_{6} \mathrm{H}_{8} \mathrm{O}$ & 0.43 \\
Ethanal & $\mathrm{C}_{2} \mathrm{H}_{4} \mathrm{O}$ & 6.34 & 3-Methyl cyclopentanone & $\mathrm{C}_{6} \mathrm{H}_{10} \mathrm{O}$ & 0.42 \\
Ethenyl Propanoic & $\mathrm{C}_{5} \mathrm{H}_{8} \mathrm{O}_{2}$ & 2.58 & 2-Butenal & $\mathrm{C}_{4} \mathrm{H}_{6} \mathrm{O}$ & 0.32 \\
1-Hidroxy-2-propanone & $\mathrm{C}_{4} \mathrm{H}_{8} \mathrm{O}_{2}$ & 2.56 & 2,3-Dihydro-1,4-dioxine & $\mathrm{C}_{4} \mathrm{H}_{6} \mathrm{O}_{2}$ & 0.27 \\
Acetic acid anhydride & $\mathrm{C}_{4} \mathrm{H}_{6} \mathrm{O}_{3}$ & 2.31 & 3-Penten-2-one & $\mathrm{C}_{5} \mathrm{H}_{8} \mathrm{O}$ & 0.18 \\
Propanal & $\mathrm{C}_{3} \mathrm{H}_{6} \mathrm{O}$ & 2.19 & 2-Pentanone & $\mathrm{C}_{4} \mathrm{H}_{10} \mathrm{O}$ & 0.17 \\
2,3-Pentanedione & $\mathrm{C}_{5} \mathrm{H}_{8} \mathrm{O}_{2}$ & 2.16 & 2,5-Hexanedione & $\mathrm{C}_{6} \mathrm{H}_{10} \mathrm{O}_{2}$ & 0.17 \\
Acetylfuran & $\mathrm{C}_{6} \mathrm{H}_{6} \mathrm{O}_{2}$ & 1.52 & Tetrahydropyran-3-one & $\mathrm{C}_{5} \mathrm{H}_{8} \mathrm{O}_{2}$ & 0.15 \\
Propanoic acid & $\mathrm{C}_{3} \mathrm{H}_{6} \mathrm{O}_{2}$ & 1.28 & Tetrahydrofuran & $\mathrm{C}_{4} \mathrm{H}_{8} \mathrm{O}$ & 0.12 \\
1-Acetyloxy-2-butanone & $\mathrm{C}_{6} \mathrm{H}_{10} \mathrm{O}_{3}$ & 1.20 & Methyl succinic anhydride & $\mathrm{C}_{5} \mathrm{H}_{4} \mathrm{O}_{3}$ & 0.11 \\
2(5H)-Furanone & $\mathrm{C}_{4} \mathrm{H}_{4} \mathrm{O}_{2}$ & 1.17 & 2-etoxy propane & $\mathrm{C}_{5} \mathrm{H}_{12} \mathrm{O}$ & 0.10 \\
\hline
\end{tabular}

Fahri Swasdika et al. 


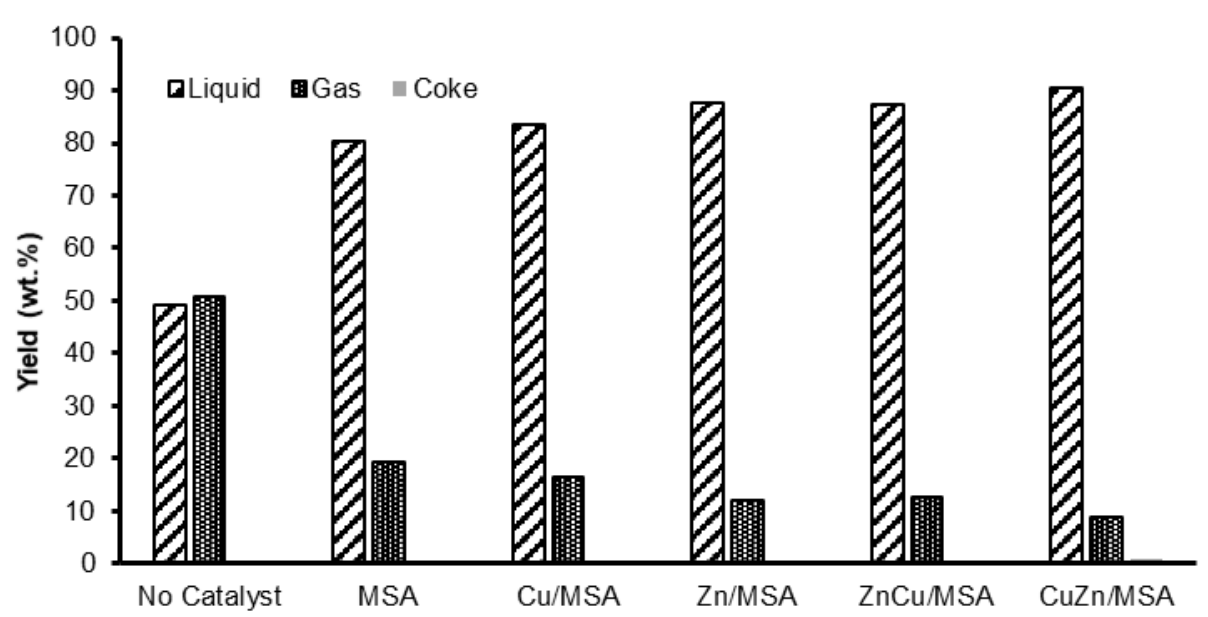

Fig 8. The product distribution of cellulose-derived bio-oil hydrotreatment

product distribution of bio-oil hydrotreatment. It can be shown that many liquid products could be obtained using catalysts more than without catalysts, while gas products could be obtained more without a catalyst. This phenomenon is expected to occur because of the differences in the reaction mechanism involved. Without a catalyst, the reaction occurs through the formation of radical ion triggered by high temperature to produce short-chain carbon compounds, while in the presence of a catalyst, the reaction takes place via the formation of the carbocation to produce longer chain carbon compounds [33]. The short-chain carbon compounds would tend to be in the gaseous phase, while the longer chain carbon compounds would tend to be in the liquid phase.

Among these catalysts, CuZn/MSA catalyst has better performance in producing liquid product than others. This phenomenon was caused by the synergetic effect between $\mathrm{Cu}$ and $\mathrm{Zn}$ metals. The presence of $\mathrm{Zn}$ metals in the bimetallic catalysts electron density on copper and can store or activate hydrogen during the hydrotreatment process [12]. The presence of $\mathrm{Zn}$ as the co-promotor can also increase the dispersion of copper particles. The good dispersion of copper particle enhances the effectiveness of the catalyst to produce liquid products.

Comparing to the previous studies, CuZn/MSA catalysts have better performance to produce liquid product. The liquid product that could be obtained using CuZn/MSA catalyst is 90.49 (wt.\%). The previous study reported a various hydrotreatments of cellulose-derived bio-oil using some catalysts, such as Ni/MSA, Mo/MSA, NiMo/MSA, and MoNi/MSA [23]. The highest yield of liquid product of 85.29 (wt.\%) could be obtained using MoNi/MSA catalyst. The other previous study also reported hydrotreatment of cellulose-derived bio-oil using $\mathrm{Co} / \mathrm{MSA}, \mathrm{Mo} / \mathrm{MSA}$, and $\mathrm{CoMo} / \mathrm{MSA}$ catalysts, which the highest yield of liquid product of 82.13 (wt.\%) could be obtained using CoMo/MSA catalyst [22].

The chemical composition of the liquid product of bio-oil hydrotreatment was analyzed using GC-MS. It is known that the hydrotreatment of bio-oil involves very complicated reactions, however, the exact mechanism has not been fully understood. These complicated reactions are due to the fact that the bio-oil contains various compounds. Therefore, we focused on the major compounds contained in the liquid product. The major compounds in the liquid product are shown in Table 3. The number of compounds in the upgraded bio-oil was less than in bio-oil. The hydrotreatment of bio-oil significantly reduces several compounds, especially compounds of ketone group such as 2,3-butanedione. Methanoic acid is also reduced during hydrotreatment processes. Reducing the acids could improve the quality of bio-oil because the acids especially formic acid and acetic acid contribute to the acidity of bio-oil [8]. The hydrotreatment process could produce hydrocarbon such as n-hexane using MSA catalysts. These results show the MSA catalysts have high selectivity for producing $n$-hexane. 
Table 3. Major compounds in bio-oil and upgraded bio-oil

\begin{tabular}{lccccccc}
\hline & \multicolumn{7}{c}{ Product percentage (wt.\%) } \\
\cline { 2 - 8 } Compound & Bio-oil & \multicolumn{5}{c}{ Catalytic upgrading* } \\
\cline { 2 - 8 } & & No catalyst & MSA & Cu/MSA & Zn/MSA & ZnCu/MSA & CuZn/MSA \\
\hline$n$-Hexane & - & - & 17.49 & - & - & - & - \\
Ethanal & 6.34 & 4.19 & 14.41 & 9.93 & 9.75 & 11.28 & 8.00 \\
2,3-butanadione & 13.54 & - & - & 2.65 & - & - & - \\
Methanoic acid & 12.72 & - & - & 0.45 & - & 1.15 & 0.81 \\
Ethanoic acid & 12.34 & 11.90 & - & 11.23 & 13.13 & 12.51 & 19.79 \\
2-Furancarboxaldehyde & 10.61 & 7.31 & 13.06 & 22.51 & 24.13 & 18.00 & 15.07 \\
1-Hydroxy-2-propanone & 20.14 & 11.95 & 10.78 & 7.72 & 6.41 & 10.73 & 18.12 \\
\hline
\end{tabular}

\section{- CONCLUSION}

In this study, the preparation of heterogeneous catalysts by a wet impregnation method was successfully carried out. Catalysts comprising $\mathrm{Cu}$ and/or $\mathrm{Zn}$ supported on MSA denoted as $\mathrm{Cu} / \mathrm{MSA}, \mathrm{Zn} / \mathrm{MSA}, \mathrm{ZnCu} / \mathrm{MSA}$, and $\mathrm{CuZn/MSA}$ were used for hydrotreatment of cellulosederived bio-oil. The synthesized MSA presented a BET specific surface area of $200.52 \mathrm{~m}^{2} \mathrm{~g}^{-1}$, a total pore volume of $0.817 \mathrm{cc} \mathrm{g}^{-1}$, and a pore diameter of $11.44 \mathrm{~nm}$. The acidity of MSA increased after metal loading, which the highest acidity of $24.86 \mathrm{mmol} \mathrm{g}^{-1}$ belonged to CuZn/MSA. During hydrotreatment of cellulose-derived bio-oil CuZn/MSA with total acidity, copper loading, zinc loading, and specific surface area of $24.86 \mathrm{mmol} \mathrm{g}^{-1}, 5.23 \mathrm{wt} . \%, 3.15 \mathrm{wt} . \%$, and $170.77 \mathrm{~m}^{2} \mathrm{~g}^{-1}$, respectively, exhibited the best performance compared to other prepared catalysts with 90.49 wt.\% conversion of liquid product.

\section{- ACKNOWLEDGMENTS}

This research was conducted under the research grant of PUPT 2018 Universitas Gadjah Mada (Contract No.: 1923/UN1/DITLIT/DIT-LIT/LT/2018). Therefore, the authors thank The Ministry of Research, Technology and Higher Education, the Republic of Indonesia for financial support.

\section{- REFERENCES}

[1] Cheng, F., and Brewer, C.E., 2017, Producing jet fuel from biomass lignin: Potential pathways to alkylbenzenes and cycloalkanes, Renewable Sustainable Energy Rev., 72, 673-722.
[2] Wang, S., Dai, G., Yang, H., and Luo, Z., 2017, Lignocellulosic biomass pyrolysis mechanism: A state-of-the-art review, Prog. Energy Combust. Sci., $62,33-86$.

[3] Czernik, S., and Bridgwater, A.V., 2004, Overview of applications of biomass fast pyrolysis oil, Energy Fuels, 18 (2), 590-598.

[4] Xiu, S., and Shahbazi, A., 2012, Bio-oil production and upgrading research: A review, Renewable Sustainable Energy Rev., 16 (7), 4406-4414.

[5] Hossain, A.K., and Davies, P.A., 2013, Pyrolysis liquids and gases as alternative fuels in internal combustion engines - A review, Renew. Sustain. Energy Rev., 21, 165-189.

[6] Saidi, M., Samimi, F., Karimipourfard, D., Nimmanwudipong, T., Gates, B.C., and Rahimpour, M.R., 2014, Upgrading of ligninderived bio-oils by catalytic hydrodeoxygenation, Energy Environ. Sci., 7 (1), 103-129.

[7] Cheng, S., Wei, L., Julson, J., Muthukumarappan, K., Kharel, P.R., and Boakye, E., 2017, Hydrocarbon bio-oil production from pyrolysis bio-oil using non-sulfide Ni-Zn/ $/ \mathrm{Al}_{2} \mathrm{O}_{3}$ catalyst, Fuel Process. Technol., 162, 78-86.

[8] He, Z., and Wang, X., 2012, Hydrodeoxygenation of model compounds and catalytic systems for pyrolysis bio-oils upgrading, Catal. Sustainable Energy, 1 (2013), 28-52.

[9] Wang, Y., Wu, J., and Wang, S., 2013, Hydrodeoxygenation of bio-oil over Pt-based supported catalysts: Importance of mesopores and 
acidity of the support to compounds with different oxygen contents, RSC Adv., 3 (31), 12635-12640.

[10] Lee, H., Kim, H., Yu, M.J., Ko, C.H., Jeon, J.K., Jae, J., Park, S.H., Jung, S.C., and Park, Y.K., 2016, Catalytic hydrodeoxygenation of bio-oil model compounds over Pt/HY catalyst, Sci. Rep., 6, 28765.

[11] Yuan, P., Liu, Z., Zhang, W., Sun, H., and Liu, S., 2010, $\mathrm{Cu}-\mathrm{Zn} / \mathrm{Al}_{2} \mathrm{O}_{3}$ Catalyst for the hydrogenation of esters to alcohols, Chin. J. Catal., 31 (7), 769-775.

[12] Gao, C., Xiao, X., Mao, D., and Lu, G., 2013, Preparation of L-phenylalaninol with high ee selectivity by catalytic hydrogenation of Lphenylalaninate over $\mathrm{Cu} / \mathrm{ZnO} / \mathrm{Al}_{2} \mathrm{O}_{3}$ catalyst, Catal. Sci. Technol., 3 (4), 1056-1062.

[13] Shi, Z., Xiao, X., Mao, D., and Lu, G., 2014, Effects of the preparation method on the performance of the $\mathrm{Cu} / \mathrm{ZnO} / \mathrm{Al}_{2} \mathrm{O}_{3}$ catalyst for the manufacture of $\mathrm{L}$ phenylalaninol with high ee selectivity from Lphenylalanine methyl ester, Catal. Sci. Technol., 4 (4), 1132-1143.

[14] Zha, F., Ding, J., Chang, Y., Ding, J., Wang, J., and $\mathrm{Ma}, \mathrm{J} ., 2012, \mathrm{Cu}-\mathrm{Zn}-\mathrm{Al}$ Oxide cores packed by metaldoped amorphous silica-alumina membrane for catalyzing the hydrogenation of carbon dioxide to dimethyl ether, Ind. Eng. Chem. Res., 51 (1), 345-352.

[15] Chiang, C.L., Lin, K.S., and Chuang, H.W., 2018, Direct synthesis of formic acid via $\mathrm{CO}_{2}$ hydrogenation over $\mathrm{Cu} / \mathrm{ZnO} / \mathrm{Al}_{2} \mathrm{O}_{3}$ catalyst, J. Cleaner Prod., 172, 1957-1977.

[16] Mascal, M., Dutta, S., and Gandarias, I., 2014, Hydrodeoxygenation of the angelica lactone dimer, a cellulose-based feedstock: Simple, high-yield synthesis of branched $\mathrm{C}_{7}-\mathrm{C}_{10}$ gasoline-like hydrocarbons, Angew. Chem. Int. Ed., 53 (7), 1854-1857.

[17] Brands, D.S., Poels, E.K., and Bliek, A., 1999, Ester hydrogenolysis over promoted $\mathrm{Cu} / \mathrm{SiO}_{2}$ catalysts, Appl. Catal., A, 184 (2), 279-289.

[18] Loricera, C.V., Castaño, P., Infantes-Molina, A., Hita, I., Gutiérrez, A., Arandes, J.M., Fierro, J.L.G., and Pawelec, B., 2012, Designing supported $\mathrm{ZnNi}$ catalysts for the removal of oxygen from bio-liquids and aromatics from diesel, Green Chem., 14 (10), 2759-2770.
[19] Verma, D., Kumar, R., Rana, B.S., and Sinha, A.K., 2011, Aviation fuel production from lipids by a single-step route using hierarchical mesoporous zeolites, Energy Environ. Sci., 4 (5), 1667-1671.

[20] Vít, Z., Gulková, D., Kaluža, L., Bakardieva, S., and Boaro, M., 2010, Mesoporous silica-alumina modified by acid leaching as support of Pt catalysts in HDS of model compounds, Appl. Catal., B, 100 (3-4), 463-471.

[21] Vít, Z., Gulková, D., Kaluža, L., and Kupčík, J., 2015, $\mathrm{Pd}-\mathrm{Pt}$ catalysts on mesoporous $\mathrm{SiO}_{2}-\mathrm{Al}_{2} \mathrm{O}_{3}$ with superior activity for HDS of 4,6-dimethyldibenzo thiophene: Effect of metal loading and support composition, Appl. Catal., B, 179, 44-53.

[22] Marsuki, M.F., Trisunaryanti, W., Falah, I.I., and Wijaya, K., 2018, Synthesis of Co, Mo, Co-Mo and Mo-Co catalysts, supported on mesoporous silicaalumina for hydrocracking of $\alpha$-cellulose pyrolysis oil, Orient. J. Chem., 34 (2), 955-962.

[23] Kusumastuti, H., Trisunaryanti, W., Falah, I.I., and Marsuki, M.F., 2018, Synthesis of mesoporous silica-alumina from Lapindo mud as a support of $\mathrm{Ni}$ and Mo metals catalysts for hydrocracking of pyrolyzed a-cellulose, Rasayan J. Chem., 11 (2), 522-530.

[24] Mahardika, I.B.P., Trisunaryanti, W., Triyono, T., Wijaya, D.P., and Dewi, K., 2017, Transesterification of used cooking oil using $\mathrm{CaO} / \mathrm{MCM}-41$ catalyst synthesized from Lapindo mud by sonochemical method, Indones. J. Chem., 17 (3), 509-515.

[25] Ahmad, M., and Benjakul, S., 2011, Characteristics of gelatin from the skin of unicorn leatherjacket (Aluterus monoceros) as influenced by acid pretreatment and extraction time, food Hydrocolloids, 25 (3), 381-388.

[26] Xu, S., Yang, H., Shen, L., and Li, G., 2017, Purity and yield of collagen extracted from southern catfish (Silurus meridionalis Chen) skin through improved pretreatment methods, Int. J. Food Prop., 20 (Suppl. 1), S141-S153.

[27] Trisunaryanti, W., Lisna, P.S., Kartini, I., Sutarno, Falah, I.I., and Triyono, 2016, Extraction of gelatin from bovine bone and its use as template in 
synthesis of mesoporous silica, Asian J. Chem., 28 (5), 996-1000.

[28] Saraswathi, P., and Makeswari, M., 2017, Preparation and characterization of alumina and silica modified chitosan, Rasayan J. Chem., 10 (3), 759-765.

[29] Gustian, I., Ghufira, and Oktiarni, D., 2017, Composite membranes based on sulfonated polysulfone and natural zeolite for proton exchange membrane fuel cells, Rasayan J. Chem., 10 (3), 689694.

[30] Saber, O., and Gobara, H.M., 2014, Optimization of silica content in alumina-silica nanocomposites to achieve high catalytic dehydrogenation activity of supported Pt catalyst, Egypt. J. Pet., 23 (4), 445-454.

[31] Wang, X., Ma, K., Guo, L., Tian, Y., Cheng, Q., Bai, X., Huang, J., Ding, T., and Li, X., 2017,
$\mathrm{Cu} / \mathrm{ZnO} / \mathrm{SiO}_{2}$ Catalyst synthesized by reduction of $\mathrm{ZnO}$-modified copper phyllosilicate for dimethyl ether steam reforming, Appl. Catal., A, 540, 37-46.

[32] Karnjanakom, S., Guan, G., Asep, B., Du, X., Hao, X., Yang, J., Samart, C., and Abudula, A., 2015, A green method to increase yield and quality of biooil: Ultrasonic pretreatment of biomass and catalytic upgrading of bio-oil over metal $(\mathrm{Cu}, \mathrm{Fe}$ and/or $\mathrm{Zn}) / \gamma-\mathrm{Al}_{2} \mathrm{O}_{3}$, RSC Adv., 5 (101), 8349483503.

[33] Pongsendana, M., Trisunaryanti, W., Artanti, F.W., Falah, I.I., and Sutarno, 2017, Hydrocracking of waste lubricant into gasoline fraction over CoMo catalyst supported on mesoporous carbon from bovine bone gelatin, Korean J. Chem. Eng., 34 (10), 2591-2596. 